\title{
THE IMPACT OF SOCIAL MEDIA MARKETING ON CUSTOMER RELATIONSHIP DEVELOPMENT
}

\author{
Aleksandra Stojiljković \\ Faculty of Economics in Subotica, University of Novi Sad; Republic of Serbia \\ aleksandra.stojiljkovic@gmail.com
}

\section{Original Scientific Paper doi:10.5937/jouproman7-22586}

\begin{abstract}
The research of digital marketing trends has shown that Social Media Marketing is at the very top of the list in popularity among digital marketing techniques on a global level. Numerous arguments which can be found in specialized and scientific literature illustrating the importance of Social Media Marketing in contemporary marketing practice, as well as the obvious topicality of this media, have been reason enough for further research. Considering the fact that customers and customer relationship development have become business imperative of every company, this marketing technique has been studied within the context of customer relationship development. The research results show that Social Media Marketing greatly influences customer relationship development.
\end{abstract}

Keywords: Social Media Marketing, Customer relationship management, Research

\section{Introduction}

Social media has become a global phenomenon since the expected number of social media users worldwide (Statista, 2019) will reach about 3.02 billion monthly active social media users till 2021, which makes up about one-third of the total population on Earth. Even though social media is ubiquitous, its market potential is still growing, since not only the number of users but also their social media engagement is still increasing. On average, Internet users worldwide spend about 135 minutes per day surfing social networks.
All this indicates great social media potential and it prompts global brands and its marketing experts to use that potential to promote their products and services through social media marketing or to use social media for advertising.

Social media comprises numerous and various media, such as social network sites (Facebook, Linkedin and MySpace), blogs, wikis (Wikipedia), podcasts, forums, content communities and microblogs (Wang and Abdullayeva, 2011). Marketing experts are thus given "a voice" and a way to connect with the associates, buyers and potential buyers (SI, 2016). Social media (Bauer, 2013; according to Inkfoundry, 2009, p. 126) "has made it possible for companies to present themselves to a new audience, create new lines of communication, deepen the relationship with the existing users and solve crises." Reasons for social media marketing popularity (Wang and Abdullayeva, 2011) have also been seen in the fact that social media is important for online business transactions due to their positive effect on customer satisfaction. They think that online "word-of-mouth" and generating users' data by the sellers, as two significant aspects of social media, have a positive impact on the user's intention to buy a product. 
The main advantage of social media marketing (Nadaraja and Yazdanifard, 2013 , p. 3) is "reducing costs and enhancing reach, since social media platforms are mainly cheaper than other marketing platforms, and social media marketing allows companies to reach customers who are not accessible due to temporal or location limitations of existing distribution channels."

On the other hand, strategic focus, which used to be exclusively sale-oriented, is nowadays shifted towards customers and their needs which have led to (Lovreta, Berman, Petkovic, Veljkovic, Crnkovic and Bogetic, 2010, p. 39) "a new marketing paradigm based on more solid relationship with customers and other stakeholders" - customer relationship management (CRM). Attracting new buyers turns into focusing on profitable long-term customer retention in the contemporary marketing paradigm. Buttle and Maklan (2015, p.4) define CRM as “ an integrated approach to identifying, acquiring and retaining customers, and enabling organizations to manage and coordinate customer interactions across multiple channels, departments, lines of business and geographical areas. CRM helps organizations maximize the value of every customer interaction and enables better corporative performance"

The long-term customer retention is possible to achieve only through developing and fostering of company's relationship with each customer separately, constantly providing higher value for the customer, which again is achievable only if a company successfully develops partnership and cooperation with all participants in the marketing channel. Social media can greatly contribute to this process.
Having considered both growing trends, the following research questions have been formulated: What is the relation between the use of social media marketing and customer relationship? Does social media marketing influence customer relationship development? How does social media marketing influence customer relationship development?

Considering its significance and topicality, numerous authors have been researching social media marketing and various literatures can be found on this subject and yet, there is a lot to study, especially within the context of its impact on customer relationship development. This paper aims to provide answers to the research questions, and the obtained results can be of use to companies in creating their own marketing strategy. Additionally, it should be brought to attention that this research was done in Serbia and that it specifically deals with examining the attitude of Serbian consumers towards social media marketing and acceptance of social media by Serbian consumers. There have been few types of research or none of this sort, and the literature on this subject is scarce. Therefore, this paper can contribute to social media marketing theory and practice in Serbia.

\section{Methodology}

\subsection{Research Model}

In order to provide answers for the research questions and prove formulated hypotheses, the research was modelled after (Osterwalder and Pigneur, 2002) ebusiness model ontology (e-business), which is based on four main pillars: (1) product innovation, (2) infrastructure management, (3) customer relationship and (4) financials. 
Considering that the paper's aim was to examine the impact of social media marketing on customer relationship development, the focus is set on the segment of the original model which refers to customer relationship and which comprises three key areas: (1) information strategy, (2) feel and serve and (3) trust and loyalty. Based on the original research model, a new research model was developed and adapted for the requirements of this research. It consists of two segments since this research has involved both examination of mobile marketing impact and social media marketing impact on customer relationship development. This paper includes only the segment related to examining the impact of social media marketing on customer relationship development.

The first segment refers to customers' socio-demographic characteristics (gender, age, education, employment, monthly income). The second segment refers to the customer experience with social media (whether they made online purchases, how they access social media, which social media they use most, and for what purposes). This part has its subcategories: (1) Relation between social media and information strategy - this segment examines the way social media influence distribution and generation of company's data by customers, which was the basis for formulating hypothesis H1: Social media use positively affects information strategy, (2) Relation between social media and feel and serve - based on the mentioned model, this part examines the way social media influence customer awareness of a product and their attitudes towards a certain product or service, which is what hypothesis $\mathrm{H} 2$ is based on - social media use positively affects feel and serve, (3) Relation between social media and trust and loyalty - it refers to examining social media impact on customers trust regarding information obtained on social media, company reputation and their imapct on customer loyalty to the brand, as one of the most important segments of the consumer relationship, which suggested hypothesis H3: Social media use positively affects trust and loyalty and (4) Relation between social media and customer relationship this part refers to whether social media marketing contributes to customer relationship development in the outcome, and this was basis for hypothesis $\mathrm{H} 4$ : Social media use positively affects customer relationship.

\subsection{Data Collection}

Following the purpose and aim of this research, and after conducting a thorough analysis, a questionnaire was selected as the most appropriate method of data collection. The questionnaire comprised four parts and 35 closed-ended questions, while Likert scale with 1 to 5 points was used for some questions (strongly disagree -1 , disagree -2 , neutral -3 , agree -4 , strongly agree - 5). A link to the questionnaire was sent to about 300 respondents with the survey instructions. After dismissing unfilled or partially filled questionnaires, the number was down to 255 respondents which represent the number of total sample respondents in this research. Both simple and complex methods were used in the process of data analysis of actual research. Professional statistical analysis software SPSS was used in obtaining statistical results, which are presented in the paper.

\section{Data Analysis and Empirical Results of the Research}

In order to provide answers to specific research questions and to test out the research hypotheses, it was necessary to conduct a preliminary analysis of data gathered from the testing (descriptive statistics). 
The results of the preliminary data analysis showed that the sample $(\mathrm{n}=255)$ included male $(52.2 \%)$ and female $(47.8 \%)$ respondents almost equally, while two age groups were dominant: 36 to 50-year-old respondents $(46.7 \%)$ and 21 to 35 - yearold respondents $(45.9 \%)$. Analysis of the education level shows that most respondents have university degrees $(56.1 \%)$. Although the majority of the respondents are employed $(85.9 \%)$, their monthly incomes are widely heterogeneous. If respondents' characteristics are observed concerning social media, the following can be noticed: most respondents $(83.5 \%)$ made online purchases, a device used most to access social media is a mobile phone $(71.0 \%)$, and social networks $(78.0 \%)$ are most frequently used social media platforms. The most common reason for social media use is to contact family and friends $(55.3 \%)$

Mean, median, standard deviation, value range of variables, asymmetry and flatness of distribution were used to provide descriptive statistical indicators of social media marketing elements (social media use, information strategy, feel and serve, trust and loyalty, customer relationship). All elements of social media marketing were estimated using the Likert scale - 5point scale (strongly disagree - 1, disagree -2 , neutral -3 , agree -4 , strongly agree 5)

Reliability of the scale of measure was assessed by means of Cronbach's alpha which value varies from 0 to 1 . According to DeVellis (2003), it is recommended not to accept the scale of measure reliability which is less than 0.7. The statistics for scale of measure reliability for all research cases (variables) are shown below (Table $1)$.

Based on the results of reliability assessing, Cronbach's alpha is 0.953 for social media marketing scale, which presents desirable reliability and internal consistency score of the scale for this sample.

The reliability statistics for each research subscale is also shown in this paper (Table 2). Considering the fact that trust and loyalty, as well as customer relationship in social media marketing, are operationalized as single-item measures, they were not included in the analysis of the subscale reliability. Having determined the reliability of separate research subscales, it can be concluded that analyzed scales have a higher level of reliability and internal consistency.

Given that the results of the KolmogorovSmirnov and Shapiro-Wilk test for mobile marketing elements showed that normal distribution assumption was not confirmed, normality is thus seen as statistically non-significant (random) deviation from normality if significance is $>0.05$ and in this case test significance was less than 0.05 . In the further course of the research, nonparametric statistical techniques were used to test hypotheses related to the presented variables.

\section{Table 1. Reliability of scale of measure statistics}

\begin{tabular}{lccc}
\hline Scale & Cronbach's alpha & $\begin{array}{c}\text { Cronbach's alpha based on } \\
\text { standardized items }\end{array}$ & Number of statements \\
\hline Social media marketing &, 953 &, 953 & 12 \\
\hline Source: Author's calculations & & \\
\hline \hline
\end{tabular}


Table 2. Reliability of subscales statistics

\begin{tabular}{lccccc}
\hline Subscale & Mean & Variance & $\begin{array}{c}\text { Standard } \\
\text { deviation }\end{array}$ & $\begin{array}{c}\text { Number of } \\
\text { statements }\end{array}$ & $\begin{array}{c}\text { Cronbach's } \\
\text { alpha }\end{array}$ \\
\hline Use (social media marketing) & 14.99 & 26.716 & 5.169 & 5 & .893 \\
Information strategy & 10.97 & 17.936 & 4.235 & 4 & .888 \\
\hline
\end{tabular}

Source: Author's calculations

\subsection{Determining statistically significant relationship between social media use and information strategy}

One of the tasks of this research was to determine the relationship between social media use and information strategy. The following hypothesis was put forward

\section{H1: Social media use is positively related to information strategy.}

Bearing in mind that assumption of normal distribution of variables was not confirmed (Kolmogorov-Smirnov and Shapiro-Wilk test), the relationship between social media use and information strategy was tested by means of Spearman's rank-order correlation (Table 3). $\mathrm{n}=255, \mathrm{p}<0.01$, was calculated between social media use and information strategy, which leads to the conclusion that a higher level of company's social media use follows better information strategy, i.e. better-informed customers. Social media use accounts for $58.37 \%$ of the variance for customers' information strategy.

Since strong positive correlation, which is statistically significant, was calculated between companies' use of social media and customers' information strategy, it can be concluded that $\boldsymbol{H} 1$ assumption is accepted, i.e. Social media use is positively related to information strategy

Strong positive correlation $(\mathrm{r}=0.764)$,

Table 3. Correlation between social media use and information strategy

\begin{tabular}{|c|c|c|c|c|}
\hline & & & Social media use & Information strategy \\
\hline \multirow{6}{*}{$\begin{array}{l}\text { Spearman rank- } \\
\text { order correlation } \\
\text { coefficient }\end{array}$} & \multirow{3}{*}{ Social media use } & Correlation coefficient & 1.000 & $.764^{* *}$ \\
\hline & & Significance & . & .000 \\
\hline & & Number of statements & 255 & 255 \\
\hline & \multirow{3}{*}{ Information strategy } & Correlation coefficient & $.764^{* *}$ & 1,000 \\
\hline & & Significance & .000 & . \\
\hline & & Number of statements & 255 & 255 \\
\hline
\end{tabular}




\subsection{Determining statistically significant relationship between social media use and feel and serve}

One of the tasks of this research was to determine relationship between social media use and feel and serve. The following hypothesis was put forward H2: Social media use is positively related to feel and serve.

Bearing in mind that assumption of normal distribution of variables was not confirmed (Kolmogorov-Smirnov and Shapiro-Wilk test), the relationship between social media use and feel and serve was tested by means of Spearman's rank-order correlation (Table 4).

A strong positive correlation $(\mathrm{r}=0.793)$, $\mathrm{n}=255, \mathrm{p}<0.01$, was calculated between social media use and feel and serve, which leads to the conclusion that a higher level of companies' use of social media follows higher customers' commitment. Social media use accounts for $62.88 \%$ of the variance for customers' feel and serve.

Since strong positive correlation, which is statistically significant, was calculated between companies' use of social media and customers' commitment, it can be concluded that $\mathrm{H} 2$ assumption is accepted, i.e. Social media use is positively related to feel and serve.

\subsection{Determining statistically significant relationship between social media use and trust and loyalty}

Another task of this research was to determine the relationship between social media use and trust and loyalty. The following hypothesis was put forward H3: Social media use is positively related to trust and loyalty.

Bearing in mind that assumption of normal distribution of variables was not confirmed (Kolmogorov-Smirnov and Shapiro-Wilk test), the relationship between social media use and trust and loyalty was tested by means of Spearman's rank-order correlation (Table 5).

Moderately strong positive correlation $(\mathrm{r}=0.718), \mathrm{n}=255, \mathrm{p}<0.01$, was calculated between social media use and trust and loyalty, which leads to conclusion that higher level of companies' use of social media follows greater level of customers' trust and loyalty. Social media use accounts for $51.55 \%$ of variance for customers' trust and loyalty.

Table 4. Correlation between social media use and feel and serve

\begin{tabular}{|c|c|c|c|c|}
\hline & & & Social media use & Feel and serve \\
\hline \multirow{6}{*}{$\begin{array}{l}\text { Spearman rank- } \\
\text { order correlation } \\
\text { coefficient }\end{array}$} & \multirow{3}{*}{ Social media use } & Correlation coefficient & 1.000 & $.793^{* *}$ \\
\hline & & Significance & . &, 000 \\
\hline & & Number of statements & 255 & 255 \\
\hline & \multirow{3}{*}{ Feel and serve } & Correlation coefficient & $.793^{* *}$ & 1.000 \\
\hline & & Significance & .000 & . \\
\hline & & Number of statements & 255 & 255 \\
\hline
\end{tabular}


Table 5. Correlation between social media use and trust and loyalty

\begin{tabular}{|c|c|c|c|c|}
\hline & & & Social media use & Trust and loyalty \\
\hline \multirow{6}{*}{$\begin{array}{l}\text { Spearman rank- } \\
\text { order correlation } \\
\text { coefficient }\end{array}$} & \multirow{3}{*}{ Social media use } & Correlation coefficient & 1.000 & $.718^{* *}$ \\
\hline & & Significance & & .000 \\
\hline & & Number of statements & 255 & 255 \\
\hline & \multirow{3}{*}{ Trust and loyalty } & Correlation coefficient & $.718^{* *}$ & 1.000 \\
\hline & & Significance & 000 & . \\
\hline & & Number of statements & 255 & 255 \\
\hline
\end{tabular}

Source: Author's calculations

Since moderately strong positive correlation, which is statistically significant, was calculated between companies' use of social media and customers' trust and loyalty, it can be concluded that $\mathrm{H3}$ assumption is accepted, i.e. Social media use is positively related to trust and loyalty.

\subsection{Determining statistically significant relationship between social media use and customer relationship}

In the outcome of this research, the task was to determine the relationship between social media use and customer relationship. The following hypothesis was put forward H4: Social media use is positively related to customer relationship.

Bearing in mind that assumption of normal distribution of variables was not confirmed
(Kolmogorov-Smirnov and Shapiro-Wilk test), the relationship between social media use and customer relationship was tested by means of Spearman's rank-order correlation (Table 6).

Strong positive correlation $(\mathrm{r}=0.795)$, $\mathrm{n}=255, \mathrm{p}<0.01$, was calculated between social media use and customer relationship, which leads to conclusion that higher level of companies' use of social media follows higher customers' satisfction. Social media use accounts for $63.20 \%$ of variance for customer relationship.

Since strong positive correlation, which is statistically significant, was calculated between companies' use of social media and customers' satisfaction, it can be concluded that $\mathrm{H4}$ assumption is accepted, i.e. social media use is positively related to customer relationship. 


\begin{tabular}{|c|c|c|c|c|}
\hline & & & Social media use & $\begin{array}{c}\text { Customer } \\
\text { relationship }\end{array}$ \\
\hline \multirow{6}{*}{$\begin{array}{l}\text { Spearman rank- } \\
\text { order correlation } \\
\text { coefficient }\end{array}$} & \multirow{3}{*}{ Social media use } & Correlation coefficient & 1.000 & $.795^{* *}$ \\
\hline & & Significance & . & .000 \\
\hline & & Number of statements & 255 & 255 \\
\hline & \multirow{3}{*}{ Customer relationship } & Correlation coefficient & $.795^{* *}$ & 1.000 \\
\hline & & Significance & .000 & . \\
\hline & & Number of statements & 255 & 255 \\
\hline
\end{tabular}

$* *$. Correlation is significant at level 0,01
Source: Author's calculations

\section{Conclusion}

The aim of this research was to provide answers to the research questions. Therefore, formulated research hypotheses were tested. The research has proven that social media marketing has an impact on customer relationship, and that there is a positive correlation between them. This can be a significant indicator for companies to include social media marketing in their marketing strategies to develop long-term customer relationship. Again, it should be emphasized that this research has been conducted in Serbia and that it specifically proves that customers in Serbia have positive attitude towards accepting social media marketing, which could be of use for companies operating on the domestic market when creating their own marketing strategies. However, some limitations have to be considered, since they are related to both the size of the sample and the fact that different research techniques could be applied in different circumstances, which can be planned in future research.

\section{Literature:}

1. Bauer, I. (2013). Digitalni marketing. (1 izdanje). Beograd: Zavod za udžbenike.

2. Buttle, F., \& Maklan, S. (2015). Customer Relationship Management:
Concepts and Technologies. (3rd Edition).

Abingdon: Routledge.

3. DeVellis, R.F. (2003). Scale Development: Theory and Applications

(2nd Edition). Thousand Oaks, CA: Sage Publications, 26.

4. Lovreta, S., Berman, B., Petković, G., Veljković, S., Crnković, J., i Bogetić, Z. (2010). Menadžment odnosa sa kupcima. (1 izdanje). Beograd: Ekonomski fakultet u Beogradu, Beograd: Data Status.

5. Nadaraja, R., \& Yazdanifard, R. (2013), Social Media Marketing: Advantages and Disadvantages. Social Media Marketing, 1-10.

6. Osterwalder, A., \& Pigneur, Y. (2002). An eBusiness Model Ontology for Modeling eBusiness. 15th Bled Electronic Commerce Conference, e-Reality: Constructing the eEconomy, Bled, Slovenia, June 17-19, 2002, $1-12$.

7. SI, S. (2016). Social Media and Its Role in Marketing. Bus Eco J 7: 203.

Business and Economics Journal, 7(1), 1-5.

8. Statista (2019). Social Media Statistics \& Facts. Preuzeto u julu 2019., sa: https://www.statista.com/topics/1164/socialnetworks/

9. Wang, X., \& Abdullayeva, G. (2011). The Relationship Between Use of Social Media and Customer Relationship, From Ecommerce Model Perspective. Master thesis. School of Economics and Management, Department of Informatics, Lund University, 1-70. 